\title{
Phytoremedial effect of fruit extract of Moringa oleifera on alloxan induced diabetic model in Swiss albino mice
}

\author{
Roushan Kumari \\ Anugrah Narayan College, Patna (Bihar), India \\ Arun Kumar Singh \\ Anugrah Narayan College, Patna (Bihar), India \\ Ranjit Kumar \\ Central University of Himachal Pradesh, Dharamshala (Himachal Pradesh), India \\ Arun Kumar* \\ Mahavir Cancer Sansthan and Research Centre, Patna (Bihar), India \\ *Corresponding author. Email: drarunk31@gmail.com
}

\section{Article Info}

https://doi.org/10.31018/

jans.v13i4.3073

Received: September 28, 2021

Revised: November 28, 2021

Accepted: December 3, 2021

\section{How to Cite}

Kumari, R. et al. (2021). Phytoremedial effect of fruit extract of Moringa oleifera on alloxan induced diabetic model in Swiss albino mice . Journal of Applied and Natural Science, 13(4), 1420 - 1429. https://doi.org/10.31018/jans.v13i4.3073

\begin{abstract}
Diabetes is a metabolic disorder and global health issue. It arises because of an absolute or relative insulin deficiency that causes hyperglycemia. The study aimed to assess the antihyperglycemic, hepatoprotective, and renal protective effects of ethanolic fruit extract of Moringa oleifera, on alloxan-induced diabetic mice. Four mice were assigned to each group. Alloxan was injected at the dose of $10 \mathrm{mg} / \mathrm{kg} / \mathrm{body}$ weight intraperitoneally to make the diabetic model in mice. Control and diabetic control mice received drinking water as a placebo, while the diabetic model mice group was administered with ethanolic extract of moringa fruit at the dose of $150 \mathrm{mg} / \mathrm{kg} / \mathrm{bodyweight}$ for 12 weeks. After that, animals were sacrificed, and their blood and tissue samples were collected for biochemical and histopathological examination. The glucose level markedly $(p<0.0001)$ increased many folds in Group I (80.73 \pm 1.24 to $221.5 \pm 13.4)$ and Group II (80.73 \pm 1.24 from to $221.9 \pm 6.88)$. The level of insulin markedly $(P<0.0001)$ decreased in both groups $(6.8 \pm 0.42$ to1.378 \pm 0.19$)$ and $(6.8 \pm 0.42$ to $1.138 \pm 0.08)$ respectively. Serum hepatic and renal marker enzymes increased in the diabetic group of mice. Glucose level was meaningfully $(p<0.0001)$ decreased in the $M$. oleifera administered group while serum insulin level significantly $(p<0.0001)$ increased. The level of liver marker enzyme and renal marker also decreased as compared to the diabetic control group. Histopathological study revealed that alloxan treatment caused damage to the liver, kidney, and pancreatic tissues while the $M$. oleifera administered group exhibited significant improvement in the architecture of the liver, kidney, and pancreas. Hence, M. oleifera has great potential to rejuvenate the damaged tissue and consequently can restore all the serum enzymatic and hormonal parameters.
\end{abstract}

Keywords: Diabetes, Insulin assay, Kidney, Liver, Moringa fruit extract, Pancreas

\section{INTRODUCTION}

Diabetes mellitus is described as a group of metabolic disorders in which a person has high blood glucose levels, either because insulin production is inadequate, or because the body cells do not respond properly to insulin or both" (Deepthi et al., 2017). Patients with high blood glucose levels will experience polyuria, polydipsia, and polyphagia (Lal, 2016). Diabetes is categorized into three major types: Type I, Type II and gestational diabetes (CDC, 2017). In India, 69.1 million people are affected by diabetes and India will soon have the second-highest number of cases in the world (Sanjeevaiah et al., 2019). In India, the prev- alence of diabetes is maximum in the southern part of the country range from 5 to $17 \%$ (Sanjeevaiah et al., 2019). Diabetes mellitus is expected to become the seventh important cause of mortality in the globe by 2030 and total deaths from hyperglycemia are predicted to increase by more than $50 \%$ in the next 10 years (Mathers and Loncar 2006). Chronic diabetes facilitates oxidative stress and plays a significant role in the pathogenesis of diabetes-related problems (Sreekutty and Mini 2016). In the case of diabetes, a cell can not utilize glucose as an energy source which then remains in the blood and ultimately accumulates in the tiny vessels of the kidney, heart, eyes and, nervous system and damages them (Mathenge et al., 
2010). If left untreated, diabetes can lead to cardiovascular diseases, blindness, and neural disorders (Sanjeevaiah et al., 2019). WHO has identified 21,000 medicinal plants with great medicinal values and have been used for many diseases worldwide. Many of them have been known to possess antihyperglycemic activity and produce natural antioxidants (Belal et al., 2017). The present hypoglycemic drugs have potential toxicity as well as lack of efficacy. Therefore, the ideal antidiabetic drug should have a combination of both antidiabetic and antioxidant activity (Krentz et al., 2016). Antidiabetic drugs are either too expensive or have undesirable complications, including hematological, coma, and liver and kidney disorders. At present, only insulin and oral medicines are available to manage the high blood glucose levels in type-1 diabetes (Hosseini et al., 2015).

Moringa oleifera belongs Moringaceae family. Moringa has high nutritional value with great medicinal properties. Every part of the moringa tree is edible. It has long been consumed by humans. It is an exceptional natural source of digestible proteins, minerals, mainly iron, amino acids, and antioxidants (M Halaby et al., 2013). Moringa has several phytochemicals such as simple sugar (rhamnose), alkaloids, flavonoids, glycosides sterols (Doumas et al., 1973; Jain et al., 2010), and many other components like glucosinolates and isothiocyanates (Bennett et al., 2003; Fahey et al., 2001). These polyphenolic secondary metabolites are natural antioxidants that directly react with superoxide anions and lipid peroxyl radicals and subsequently prevent the series of lipid peroxidation. They perform their free radical scavenging activity by donating the hydrogen or electron to the superoxide anions hence moringa is a natural antioxidant (Rajanandh and Kavitha, 2010). It also contains a rarer combination of phenolics compounds, including zeatin, quercetin, kaempferol, and apigenin which are vital and diseases-preventing nutrients (Sreelatha et al., 2011). It is used as antitrypanosomal, hypotensive, anti-inflammatory, hypoglycemic, and hypercholesteremia (Sreelatha et al., 2011). Furthermore, moringa leaves steam and bark have been reported as antidiabetic on hyperglycemic rats, mice, and rabbits (Gupta et al., 2012; Kar et al., 2003; Luangpiom et al., 2013; Manohar et al., 2012). Francis et al. (2004) reported that methanolic moringa fruit extracts were effective against diabetes by the stimulation of insulin secretion and also had cyclooxygenase and lipid peroxidase inhibition activity. However, inadequate information on moringa fruit extract as an antidiabetic agent has been reported. Therefore, the current study was undertaken to evaluate the antidiabetic properties of ethanolic fruit extract of $M$. oleifera in an alloxan-induced diabetic model.

\section{MATERIALS AND METHODS}

\section{Experimental mice}

Twenty-four male adult Swiss albino mice were used in the experiment. Experimental mice were 12 weeks old and weighed 30 to $35 \mathrm{gm}$ at the initial period of the investigation. Animals were obtained from the animal house of Mahavir Cancer Sansthan \& Research Centre, Patna, India (CPCSEA Reg-No.1129/bc/07/ CPCSEA). They were kept under hygienic conditions in well-ventilated chambers at $23 \pm 2^{\circ} \mathrm{C}$ and $50 \pm 10 \%$ relative humidity with a $12 \mathrm{~h}$ photoperiod. They were maintained on the laboratory-prepared food, including multigrain bread, soaked grams, green vegetables, and drinking water ad libitum. They were divided into four groups (Group I to IV), each consisting of four animals. Each group was housed in distinct polypropylene cages $(26 \times 19 \times 13 \mathrm{~cm})$. All animal groups were adapted under the laboratory housing conditions for 10 days before the beginning of the experiment. All the experimental animals were accompanied as per guidelines of the Committee for control and supervision of experiments on animals (CPCSEA), New Delhi, India. Ethical approval was obtained from the Institutional Animal Ethics Committee (IAEC) of the institute with the IAEC No 2020/IE-27/08/20

\section{Preparation of medicinal plant extract}

Fresh fruits of $M$. oleifera were washed, cut into small parts, dried in the incubator at $37^{\circ} \mathrm{C}$ for 20 days, and ground to powder. Fruit powder was soaked in absolute ethanol for 48 hours. It was then dried through rotary evaporators (Buchi, R-3, Switzerland) at $60^{\circ} \mathrm{C}$ and 300 psi. The obtained extract was then stored in an airtight bottle. A fresh solution has been prepared from this stock by dissolving $150 \mathrm{mg}$ moringa extract into $5 \%$ ethanol. This extract of $M$. oleifera was administered orally (150 mg/kg/body weight/day) to the diabetic mice.

\section{Induction of diabetes}

Diabetes was induced in animals by alloxan, purchased from Loba Chemie Pvt. Ltd., Mumbai (CAS No-22244-11-3, batch No. 6209707). Twelve mice were fasted overnight and were injected with a single dose of alloxan, intraperitoneally, with a dose of 110 $\mathrm{mg} / \mathrm{kg}$ body weight. Mice were allowed free access to the food and water ad libitum. After 3 days of alloxan administration, the hyperglycemic condition was estimated by testing their fasting blood glucose levels. The blood samples were collected from the tip of the tail. The blood glucose level was estimated by one touch glucometer [Infobia Co. Ltd., Korea]. Mice having a blood glucose level equal to $198 \mathrm{mg} / \mathrm{dl}$ were considered diabetic mice. 


\section{Experimental plan}

Experimental animals were randomly divided into four groups and each group consisted of four animals. Twelve animals were used for the preparation of the diabetic model and four mice were run along with the experiment as the control.

Group I: Untreated controls received food and water only;

Group II: Diabetic controls (Alloxan administered); mice were left without any treatment throughout the experiment for auto-recovery

Group III: Diabetic (Alloxan administrated) received food and water only.

Group IV: Diabetic group; administration of the ethanolic fruit extract of moringa, @ dose of $150 \mathrm{mg} / \mathrm{kg}$ body weight/day orally once a day for 84 days.

Mice of groups I and II were sacrificed along with group IV after the accomplishment of the entire experiment. Group III was sacrificed after 15 days to evaluate the effects of alloxan.

\section{Biochemical estimation}

Mice were sacrificed by the cervical dislocation process after the accomplishment of the experiment. Blood was collected by the orbital puncture. The serum was separated from the blood through the centrifugation method, $\mathrm{rpm}$ at $3000 \mathrm{~g}$ for 15 minutes at room temperature. The collected serum was used for the biochemical assays. Biochemical parameter tests were completed by the standard commercial kit - Coral clinical system with the help of a spectrophotometer (UV-10, Thermo Scientific, USA). The serum glucose level was estimated by GOD/ POD method (Trinder, 1969). Reitman and Frankel (1957) method was used for the estimation of liver markers enzyme serum glutamic-oxaloacetic transaminase (SGOT) and glutamate pyruvate transaminase (SGPT). Jendrassik-Grofs BM (1938) method was used to estimate total bilirubin. Urea was estimated by the method of Fawcett and Scott (1960) and uric acid through the method of Fossati (1980), while creatinine was measured by the method of Bonsnes and Taussky (1945).

\section{Hormonal assay}

Estimation of Insulin levels was performed through the Enzyme-Linked Immunosorbent Assay (ELISA) method (Cal biotech, Inc.1935 Cordell Ct., El Cajon's, 92020 USA, Lot No Ins5296). The final readings were taken through the ELISA reader- AM 2100, Thermo Fisher, USA, and the generated data were interpreted.

\section{Histopathological assessment}

The mice were dissected and their tissues were taken out for the histopathological study. The small segments of the liver, kidney, and pancreas tissues were fixed into Tissue preservative (10\%) Formalin for 24 hours.
The tissues were dehydrated through the series of ethanol and were embedded into paraffin. The section of $5 \mu \mathrm{m}$ in thinness via the digital rotary microtome (Micron HM 340E, Thermo scientific, USA) was taken on the slides and were stained with hematoxylin and eosin (H\&E) and finally were observed through a light microscope.

\section{Statistical analysis}

Results were expressed as Mean \pm Standard Error Mean (SEM). The significant difference between the control and treated group for all parameters was analyzed by one-way analysis of variance (ANOVA) followed by Tukey's multiple comparison test. Statistically significant value $P<0.05$ was consider. The analysis was done using the Graph Pad Prism 5.0 program (Graph Pad Software, Inc., San Diego, USA).

\section{RESULTS}

\section{Biochemical analysis \\ Effect on glucose level}

The serum glucose levels in mice (Group I, Control) were stable throughout the experimental period. On the other hand, in the alloxan-induced diabetic group (Group II), there was a significant rise in the serum glucose levels $(p<0.0001)$ in contrast to Group I. However, diabetic mice, which were left without any treatment for 12 weeks for auto restoration, did not exhibit any natural restoration in their hyperglycemic state. Pancreatic diameter decreased significantly $(P<0.0001)$ in the diabetic model (Group II) and the diabetic control (Group III) relative to the control (Group I) (Fig. 1).

\section{Effect on the serum insulin leve}

Serum insulin levels significantly lowered down $(p<0.0001)$ in both diabetic models (Group II) and diabetic control in comparison to normal control (Group I). However, the serum insulin levels markedly increased in moringa treated group of mice. while the diabetic control group (Group III) restored the insulin levels up to 12 weeks (Fig. 2).

\section{Effect on pancreas size}

The diameter of pancreas was significantly $(p<0.0001)$ decreased in both diabetic model (Group II) and diabetic control (Group III) as compared to the control (Group I). It may happen due to free radical regeneration of alloxan and cause necrosis of Pancreas. However, in the moringa treated group (Group VI), there was a significant $(p<0.0001)$ increase in the pancreas diameter as compared to the diabetic model and diabetic control both (Fig. 3).

\section{Serum level of hepatic marker enzymes}

The results showed that alloxan-induced (Group II) had markedly $(p<0.0001)$ elevation in the serum levels of 


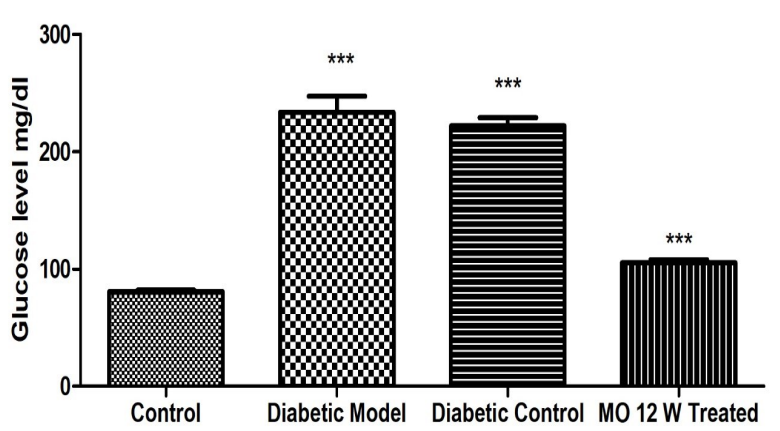

Fig. 1. Serum glucose $(\mathrm{mg} / \mathrm{dl})$ levels in different treated groups (control and treated group). Data are expressed as mean $\pm S D, n=6$. Statistical significance level was checked through the one-way ANOVA, followed by Tukey's test with multiple comparisons. The $p$-values of the diabetic group are ${ }^{* * *} p<0.0001$ compared with a control group; $M O$ $12 W$ treated group with the control group $(p<0.05)$

bilirubin, SGPT and SGOT, as compared to the normal control group (Group I). However, in an alloxan-induced diabetic control group of mice (Group III), which were kept for auto-recovery for 12 weeks after alloxan treatment, had a significant $(p<0.0001)$ decrease in the SGPT, SGOT levels, but the bilirubin levels nonsignificantly changed in comparison to the diabetic mice. But, after the administration with ethanolic moringa fruit extract with a dose of $150 \mathrm{mg} / \mathrm{kg}$ body weight per day for 12 weeks on diabetic mice, showed the defensive effect against diabetic induced hepatotoxicity as there was a significant $(p<0.0001)$ reduction in the levels of SGPT, SGOT and bilirubin levels in comparison to the diabetic control and diabetic mice (Table 1).

\section{Serum level of renal marker enzyme}

The mean value of renal marker enzyme creatinine urea, and uric acid, were markedly $(p<0.0005)$ elevated in the diabetic (group II) and diabetic control (group III) in contrast to the normal control mice. However, the alloxan-induced diabetic control group (Group III), which was kept for auto-recovery for 12 weeks after alloxan-induced, had a significant $(p<0.05)$ reduction in the urea, but uric acid and creatinine levels had a non-

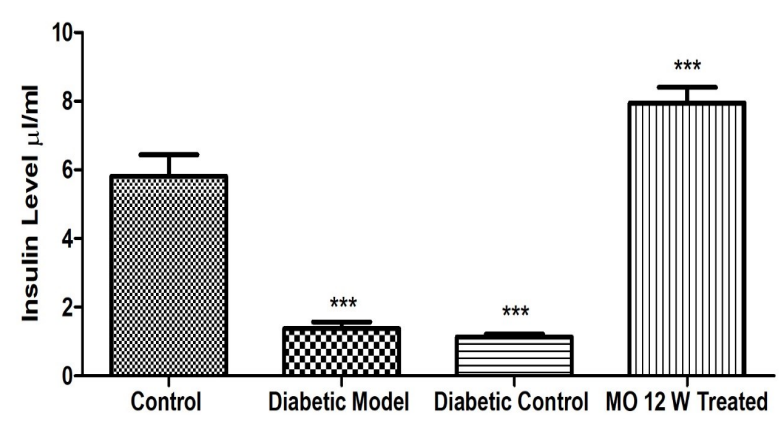

Fig. 2. Serum Insulin $(\mu \mathrm{l} / \mathrm{ml})$ levels in different treated groups (control and treated group). Values are expressed as mean $\pm S D, n=6$. Statistical significance level was analysed through the one-way ANOVA, followed by Tukey's test with multiple comparisons. The $p$-values of diabetic group $^{* * *}(p<0.0001)$ compared with a control group; MO 12 $W$ treated group with the control group $(p<0.05)$

significant change in comparison to the diabetic model. Group II but, after treatment with moringa ethanolic fruit extract over 12 weeks on diabetic model mice, it showed the defensive effect against diabetes-induced kidney damage. Creatinine, urea and uric acid were significantly $(p<0.001)$ reduced in comparison to the diabetic control and diabetic group (Table 2).

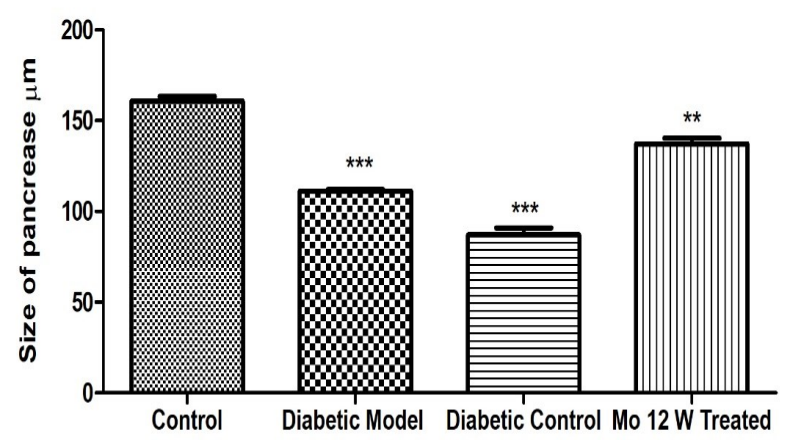

Fig. 3. Size of islets of Langerhans $(\mu \mathrm{m})$ in different treated groups (control and treated group). Values are mentioned as mean \pm SEM, $(n=6)$. Statistical significance was checked through the one-way ANOVA, followed by Tukey's test with multiple comparisons. The p-values are diabetic model group ${ }^{* * *}(p<0.0001)$ compared with a control group; MO $12 W$ treated group with control group $(p<0.05)$

Table 1. Effect of ethanolic extract of moringa fruit on liver marker enzyme

\begin{tabular}{lllll}
\hline Group & $\begin{array}{l}\text { Control } \\
\text { (Group I) }\end{array}$ & $\begin{array}{l}\text { Diabetic model } \\
\text { (Group II) }\end{array}$ & $\begin{array}{l}\text { Diabetic control } \\
\text { (Group III) }\end{array}$ & $\begin{array}{l}\text { Mo 12 w treated } \\
\text { (Group IV) }\end{array}$ \\
\hline SGPT $(\mathrm{U} / \mathrm{mL})$ & $25.25 \pm 1.79$ & $192.0 \pm 4.20^{* * *}$ & $164.0 \pm 4.52^{* * *}$ & $55.50 \pm 2.10^{* * *}$ \\
SGOT $(\mathrm{U} / \mathrm{mL})$ & $28.75 \pm 0.59$ & $206.3 \pm 6.303^{* * *}$ & $131.5 \pm 4.36^{* * *}$ & $62.58 \pm 1.81^{* * *}$ \\
Bilirubin $(\mathrm{mg} / \mathrm{dl})$ & $0.64 \pm 0.04$ & $1.95 \pm 0.15^{* * *}$ & $1.97 \pm 0.08^{\mathrm{ns}}$ & $0.72 \pm 0.11^{* * *}$ \\
\hline
\end{tabular}

Levels of liver marker enzyme in different treated groups (control and treated group). Values are mentioned as mean \pm SEM, $n=6$. Statistical significance level was analysed through the one-way ANOVA, followed by Tukey's test with multiple comparisons. The $p$ - values of diabetic model group ${ }^{\star * *}(p<0.0001)$ compared with the normal control group; MO $12 \mathrm{~W}$ treated group with the control group ( $\left.p \varangle 0.05\right)$. 
Kumari, R. et al. / J. Appl. \& Nat. Sci. 13(4), 1420 - 1429 (2021)

Table 2. Effect of the ethanolic extract of moringa fruit extract in kidney marker enzyme

\begin{tabular}{lllll}
\hline Group & $\begin{array}{l}\text { Control } \\
\text { (Group I) }\end{array}$ & $\begin{array}{l}\text { Diabetic model } \\
\text { (Group IV) }\end{array}$ & $\begin{array}{l}\text { Diabetic control } \\
\text { (Group III) }\end{array}$ & $\begin{array}{l}\text { MO 12w treated } \\
\text { (Group IV) }\end{array}$ \\
\hline Urea $(\mathrm{mg} / \mathrm{dl})$ & $22.78 \pm 0.54$ & $40.13 \pm 1.73^{* * *}$ & $48.73 \pm 0.67^{* * *}$ & $28.59 \pm 2.58^{* * *}$ \\
Uric acid $(\mathrm{mg} / \mathrm{dl})$ & $2.75 \pm 0.34$ & $9.37 \pm 0.66^{* \star *}$ & $8.95 \pm 0.53^{* \star}$ & $3.65 \pm 0.29^{* \star *}$ \\
Creatinine $(\mathrm{mg} / \mathrm{dl})$ & $1.15 \pm 0.07$ & $1.63 \pm 0.16^{* \star}$ & $1.80 \pm 0.28^{* \star}$ & $0.57 \pm 0.07^{* \star}$ \\
\hline
\end{tabular}

Levels of liver marker enzyme in different treated groups (control and treated group), Values are mentioned as mean \pm SEM, ( $n=6$ ). Statistical significance level was analyzed by the one-way ANOVA, followed by Tukey's test with multiple comparisons. The $p$-values of diabetic model group ${ }^{* * *}(p<0.0001)$ compared with the control group; MO $12 W$ treated group with the control group $(p<0.05)$.

Histopathological assessment of the hepatic tissue The liver section of normal control mice (Group I) showed the normal architecture of the central vein lined by endothelial cells, hepatic cells with a well-defined nucleus, and normal sinusoids. Cytoplasmic material was also normal. (Fig. 4A). The liver section of the alloxan diabetic mouse (group II) showed significant deterioration of the hepatocyte and central vein with the broken or irregular pattern of endothelial cells with frequent vacuolisations (Fig. 4B). The hepatic section of the diabetic control (group III) showed a slight articulation of the central vein, the portal vein, but vacuolisations in the cytoplasmic material were still persistent. There was mild amelioration observed in the hepatic tissue in the diabetic control group. It may be due to the regeneration property of the liver (Fig. 4C). The ethanolic extract of moringa fruit administration on the diabetic model, liver section showed a significant normal hepatocellular architecture which was well organized. The central vein showed necrotic nuclei or hetrochromatized nuclei with significant restoration. Hepatic cells were normal with cytoplasmic materials and sinusoids (Fig. 4D).

\section{Histopathological assessment of renal tissue}

In this histopathological examination, the control mice kidney section showed the normal structure of renal
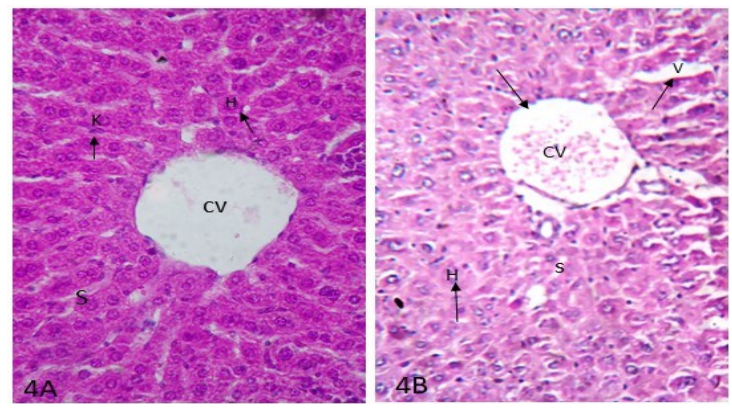

parenchyma and glomerulus in Bowman's capsule, Proximal convoluted tubules (PCT) and Distal convoluted tubules (DCT) (Group I) (Fig. 5A). The alloxaninduced mice (Group II) kidney section showed degeneration in the glomerulus; vacuolations in Bowman's capsule along with the distal and proximal convoluted tubules, dilation in renal tubules (Fig. 5B). The diabetic control (Group III) showed degeneration in the nephrocytes, thickening of the glomerular basement membrane, and cytoplasmic vacuolations which indicate auto-improvement up to twelve weeks (Fig. 5C). Bowman's capsule, glomerulus, and the distal and proximal convoluted tubules showed the normal architecture after administration of moringa fruit extract for 12 weeks upon alloxan-induced diabetic mice in comparison to the diabetic mice and diabetic model mice both (Fig. 5D).

\section{Histopathological study of the pancreatic tissue}

In this histopathological study, the pancreatic section of control (Group I) showed the normal structure of acini and islets of Langerhans. Islets showing compact spherical mass with intact interlobular connective tissue (Fig. 6A). The alloxan-induced (Group II) pancreatic section showed necrosis and vacuolization in islets of langerhans, pancreatic acini are not well organized. The number and size of islets are also reduced as com-

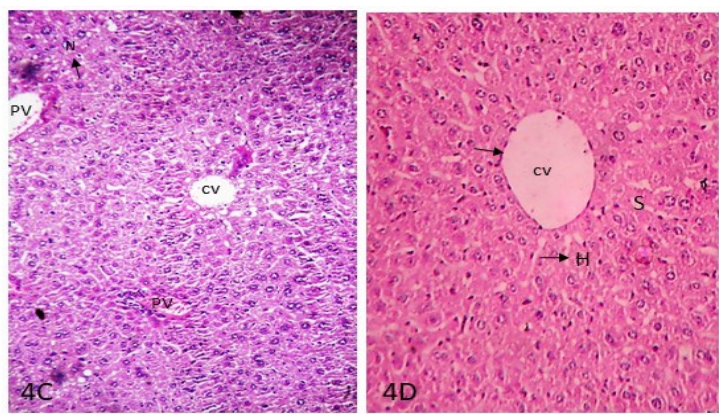

Fig. 4. Photograph of mice liver stained with hematoxylin and eosin (H\&E 500x). (A) Liver section of control mice with regular arrangement of hepatocytes $(H)$ and central vein $(C V)$, sinusoids $(S)$ and kupffer $(K)$ cells (H\&E 400x). (B) Section of alloxan-induced mice liver showing degenerated hepatocytes (H), bile duct (BD), and kupffer cells (KF) (H\&E 400x). (C) Section of alloxan-induced diabetic control mice liver with mild degeneration and vacuolization in the hepatocytes (H) due to alloxan (H\&E 400x). (D) Section of liver administered with moringa fruit extract upon diabetic mice showing significant improvement in the hepatic histoarchitecture along with the central vein (CV) and hepatic cells (H), sinusoids (S) (H\&E 400x) 
pared with the control (Fig. 6B). The diabetic control mice (Group III) also showed degeneration in acini and islets of Langerhans dilation of the intralobular duct, reduction in number and size of islets. It does not show auto-restoration (Fig. 6C). The ethanolic moringa fruit extract administration upon alloxan-induced diabetic mice pancreatic section showed significant restoration in the islets of Langerhans, normal acini, and an intralobular duct. The number and size of islets of Langerhans significantly increased as compared with the diabetic control. It shows the regeneration of islands with $\beta$ cells (Fig. 6D).

\section{DISCUSSION}

Antidiabetic properties of $M$. oleifera have been reported previously by different authors (Bamagous et al.,2018; Abd El Latif et al.,2014; villarruel-Lopez et al., 2018; Tang et al.,2017). As it is well known that fruits of $M$. Oleifera are generally consumed as a vegetable,

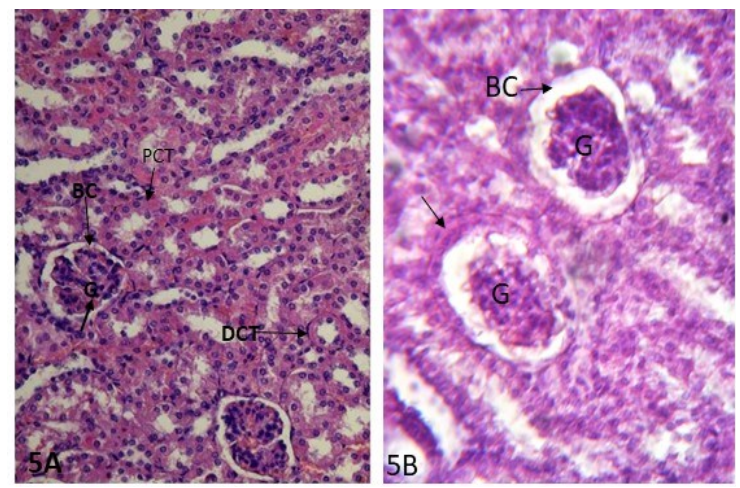

so this study is very important because it deciphers the antidiabetic effect of fruit extract on the current animal model. Therefore, the assessment and implementation of the hypoglycemic effect of Moringa fruits create a benchmark for managing diabetes.

Alloxan was used as a diabetogenic for the selective destruction of $\beta$ cells (Lenzen, 2008). After the induction of diabetes, serum glucose levels were significantly raised in comparison to the normal mice, also reported by (Durašević et al., 2019). However, after the treatment of ethanolic moringa fruit extract for twelve weeks, the glucose level of diabetic mice significantly reduced and almost in a normal range of fasting serum glucose level. Similar results have been reported, with the help of an aqueous extract of leaves of moringa in Wistar rats (Jaiswal et al., 2009), methanolic moringa extract in alloxan-induced diabetic mice (Olayaki et al., 2015). Another study was made by Hemant et al. (2013) who observed that ethanolic pod extract in alloxan diabetic rats with a concentration of $200 \mathrm{mg} / \mathrm{kg}$
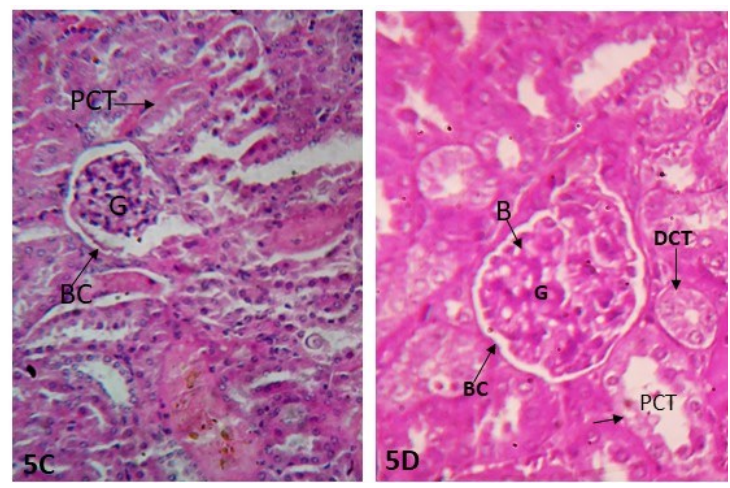

Fig. 5. Microphotograph of mice kidney stained with (H\&E). (A) Section of control mice kidney showing a normal structure of Bowman's capsule (BC) and glomerulus (G) (H\&E 400x). (B) Alloxan-induced kidney section showing deterioration in the glomerulus (G) vacuolations in the Bowman's capsule (BC) basement and proximal and distal convoluted tubules (PCT and DCT) (H\&E 400x). (C) Alloxan-induced diabetic control mice kidney section showing degeneration in the Bowman's capsule $(B C)$ and glomerulus $(G)$ along with the enlarged renal convoluted tubule denotes that there was a mild retrieval in the nephrocytes (H\&E 400x). (D) The moringa fruit extract administration upon diabetic model group showed significant restoration. It shows normal architecture with no histopathological alterations (H\&E 500x)
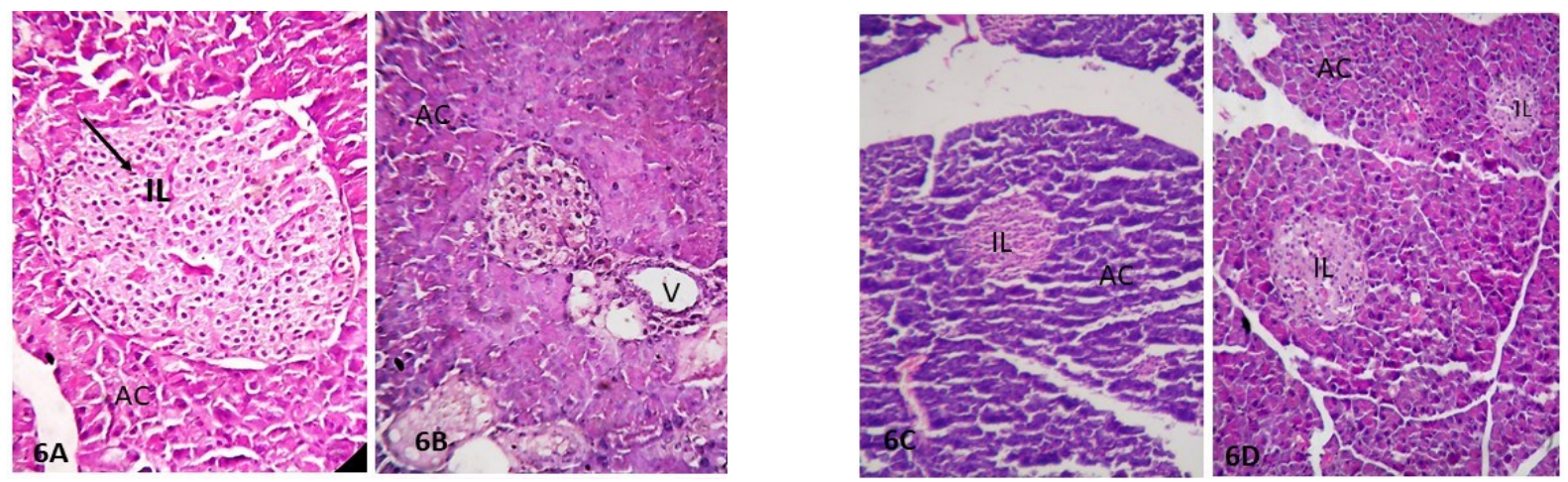

Fig. 6. A) Pancreas of mice from the negative control group showing no histopathological changes, round islets of Langerhans (IL), B) pancreas of mice from the alloxan-induced diabetic group showing necrosis and vacuolations of pancreatic acini (AC) and islets Langerhans cells and dilated intralobular duct (ID), C) the pancreas of alloxan-induced diabetic control mice showing shrinkages in islets, vacuolations in acini $(A C)$, and $(D)$ pancreas of diabetic mice treated with ethanolic moringa fruit extract showing no histopathological changes $(H \& E \times 400)$ 
showed antidiabetic properties by increasing the action of insulin. In the present study, insulin secretion from the pancreatic $\beta$-cell was significantly $(p<0.0001)$ reduced in group III from $6.8 \pm 0.42$ to $1.13 \pm 0.08$ in the alloxan-induced diabetic mice in contrast to the normal control group of mice, while after administration with the ethanolic moringa fruit extracts. The serum insulin levels in diabetic mice were significantly $(p<0.0001)$ elevated from $1.13 \pm 0.08 \pm 7.94 \pm 0.45$ after the treatment with moringa extract. Basyony et al. (2016) also found that there was a significant reduction in the insulin levels in alloxan-treated mice but, after the administration of moringa leaves for 30 days, there was a significant increase in the insulin levels in diabetic mice. Isolated $\mathrm{N}$-Benzyl thiocarbamates, benzyl nitriles, N-benzyl carbamates, and a benzyl ester from methanol extract of moringa fruit powder were reported to stimulate the insulin release from the rodent's pancreatic $\beta$-cells. Ethanolic moringa leaf extract elevates insulin levels in diabetic mice, confirmed by (Tang et al., 2017). Many authors (Karthikesan et al., 2010; Vergara-Jimenez et al., 2017) conclude that chlorogenic acid found in moringa plays an important role in maintaining the glucose levels by inhibiting the glucose 6-phosphate translocase in diabetic rats by reducing glycogenolysis and gluconeogenesis. M. oleifera fruit extract inhibits the enzymatic activity of alpha-amylase and alphaglucosidase in the intestine, which prevents the breakdown of the complex sugar into simple sugar, thus preventing the hyperglycemic condition (Kamalrudin et al., 2018). The liver plays an important role to balance the normal glucose levels in the blood, which regulates the insulin secretion and release of the inflammatory cytokines (Bamagous et al., 2018). Elevated levels of serum hepatic marker enzymes are the indicators of hepatic damage, where the enzymes are released into the bloodstream (Annadurai et al., 2012; Geleta and Makonnen, 2015). Alloxan-induced diabetic mice also showed similar results, proving the hepatic damage. Agarwal et al., 2012 also found a marked elevation in the levels of serum liver marker enzymes such as bilirubin, SGPT, and SGOT. in the alloxan-induced diabetic mice. However, oral administration of ethanolic moringa fruit extract for 12 weeks in diabetic mice showed a substantial reduction in serum hepatic marker enzyme levels compared to the diabetic control. This finding is in agreement with (Bamagous et al., 2018). Furthermore, moringa shows hepatoprotective activity against acetaminophen (Aly et al., 2020), alcohol-induced liver disorders (Muzumbukilwa et al., 2019), and cadmium toxicity (Toppo et al., 2015). This liver injury may be restored due to the antioxidant property of $M$. oleifera, which inhibits the oxidative stress associated with liver injury (Alhakmani et al., 2013). In the present study, the level of urea and uric acid significantly $(p<0.0001)$ in- creased in diabetic control (Group III) range from $22.78 \pm 0.54$ to $48.73 \pm 0.67$ and $2.75 \pm 0.34$ to $8.95 \pm 0.53$, respectively. The level of creatinine significantly $(p<0.001)$ increased from $1.63 \pm 0.16$ to $1.80 \pm 0.28$ in diabetic control (Group III) as compared to the control mice. Elevation of the enzyme due to the oxidative stress of alloxan. Additionally, our results showed marked improvement $(p<0.0001)$ in the renal marker enzymes after the administration of ethanolic moringa fruit extract in diabetic mice for twelve weeks. This finding is in agreement with (Al-Malki and El Rabey, 2015). As a result of histopathology, one important finding was observed: the size from $160.7 \pm 2.61$ to $113.3 \pm 0.84$ ) of islets of Langerhans in diabetic control mice was significantly $(p<0.0001)$ decreased in comparison to the normal control group of mice. Moreover, degeneration of pancreatic $\beta$-cells and vacuolizations was observed in diabetic albino rats, which were earlier reported by (Elkotby et al., 2018). Whereas, in the moringa administered group, there was a significant increase $(p<0.0001)$ in size from $113.3 \pm 0.84$ to $137.3 \pm 3.17$ of the islets of Langerhans with well-arranged pancreatic $\beta$ - cells. Apart from that, it almost achieved its normal architecture and these results decipher that ethanolic moringa fruit extract is involved in pancreatic cell regeneration. In another study, Gupta et al. (2012) also found the restoration in histoarchitecture of pancreatic tissue through the methanolic extract of moringa leaves extract. Moringa is a good source of antioxidants and valuable therapeutic nutrients like flavonoids, terpenoids, kaempferol, and quercetin. Therefore, it may be capable of repairing and regenerating injured pancreatic tissue and $\beta$-cell in alloxan-induced diabetic mice. These components are strong antioxidants and great free radical scavengers (Abd El Latif et al., 2014; Moyo et al., 2012; Tende et al., 2011). In the present study, the elevated serum hepatic marker showed a direct correlation with our histopathological study. In alloxaninduced diabetic mice showed degenerated hepatocytes, bile duct, and kupffer cells with degenerated nuclei and enlarged sinusoids. Lucchesi et al. (2015) also observed a similar pattern in their study, in the diabetic rat, which liver shows similar morphology same as chronic fatty liver in diabetic human patients Ethanolic moringa fruit extract effectively ameliorates hepatic tissue damage in 12 weeks. (Omodanisi et al., 2017). Alloxan-induced oxidative stress also damages the renal tissue especially causing vacuolation in the Bowman's capsule and glomerulus. This is in agreement with the study on the effect of Salvadora persica leaf extracts in alloxanized rats (Alrasheedi, 2020). Ethanolic moringa fruit ameliorates the bowman's capsule, glomerulus and distal convoluted tubules and shows normal histoarchitecture of the kidney. This is consistent with another finding who reported significant 
alterations in the renal tissue in the diabetic rat after the treatment with the methanolic moringa extract (Kandasamy and Ashok Kumar 2013; Omodanisi et al. 2017).

\section{Conclusion}

Generally, people prefer the moringa fruit in their diet over the moringa leaves and moringa fruit extract is less explored as an anti glycemic agent. Based on the experimental results, it was concluded that the fruit extract of $M$. oleifera provided potentially protection against hyperglycemia and its complications. It maintained the blood glucose levels, normalized the insulin level, and protected and rejuvenated the pancreatic islets, liver, and kidney tissue. It also improves carbohydrate metabolism, including restoring the integrity and function of the pancreatic $\beta$-cells along with the glucose uptake and utilization. Moringa extract maintains glucose homeostasis. Findings suggest that $M$. oleifera fruit extract is a potential antidiabetic drug that can reduce blood glucose levels and diabeticassociated problems.

\section{ACKNOWLEDGEMENTS}

The authors are thankful to Anugrah Narayan College, Patna, Bihar, for infrastructural facilities; and Mahavir Cancer Sansthan and Research Center, Patna, Bihar, India for the animal and laboratory facilities.

\section{Conflict of interest}

The authors declare that they have no conflict of interest.

\section{REFERENCES}

1. Agarwal, V., Sharma, A.K., Upadhyay, A., Singh, G. \& Gupta, R. (2012). Hypoglycemic effects of Citrullus colocynthis roots. Acta Pol. Pharm. - Drug Res. 69, 75-79.

2. Abd El Latif, A., El Bialy, B. E. S., Mahboub, H. D. \& Abd Eldaim, M. A. (2014). Moringa oleifera leaf extract ameliorates alloxan-induced diabetes in rats by regeneration of $\beta$ cells and reduction of pyruvate carboxylase expression. Biochemistry and cell biology, 92(5), 413-419.

3. Al-Malki, A.L. \& El Rabey, H.A. (2015). The antidiabetic effect of low doses of moringa oleifera lam. Seeds on streptozotocin induced diabetes and diabetic nephropathy in male rats. Biomed Res. Int. 2015, 1-13. https:// doi.org/10.1155/2015/381040

4. Alhakmani, F., Kumar, S. \& Khan, S.A. (2013). Estimation of total phenolic content, in-vitro antioxidant and antiinflammatory activity of flowers of Moringa oleifera. Asian Pac. J. Trop. Biomed. 3, 623-627. https://doi.org/10.1016/ S2221-1691(13)60126-4

5. Alrasheedi, A.A. \& Hijazi, M. A. (2020). Antihyperglycemic effect of Salvadora persica leaf extracts in Alloxanized rats. International Journal of Food Sciences and Nutrition, 5, 38-456.

6. Aly, O., Abouelfadl, D. M., Shaker, O. G., Hegazy, G. A., Fayez, A. M. \& Zaki, H. H. (2020). Hepatoprotective effect of Moringa oleifera extract on TNF- $\alpha$ and TGF- $\beta$ expression in acetaminophen-induced liver fibrosis in rats. Egyptian Journal of Medical Human Genetics, 21(1), $1-9$.

7. Annadurai, T., Muralidharan, A.R., Joseph, T., Hsu, M.J., Thomas, P.A. \& Geraldine, P. (2012). Antihyperglycemic and antioxidant effects of a flavanone, naringenin, in streptozotocin-nicotinamide-induced experimental diabetic rats. J. Physiol. Biochem. 68, 307-318. https:// doi.org/10.1007/s13105-011-0142-y

8. Bamagous, G.A., Al Ghamdi, S.S., Ibrahim, I.A.A., Mahfoz, A.M., Afify, M.A., Alsugoor, M.H.M., Shammah, A.A., Arulselvan, P. \& Rengarajan, T. (2018). Antidiabetic and antioxidant activity of ethyl acetate extract fraction of Moringa oleifera leaves in streptozotocin-induced diabetes rats via inhibition of inflammatory mediators. Asian Pac. J. Trop. Biomed. 8, 320-327. https://doi.org/10.4103/22211691.235327

9. Basyony, M.A., El-Desouki, Hegazy, N.I. \& El-Aama, M.M. (2016). Evaluation of anti- hyperglycemic effect of Moringa oleifera leaves extract on some physiological parameters of diabetic rats induced apoptosis in the pancreas. Int. J. Sci. Eng. Res. 7, 1461-1482.

10. Belal, H., Yesmin, R., Mamun, A., Hasan, N., Islam, D., A, I., MN, T., Rezaul, M., -2, K., Khan, M.H., Hossain, M.I., Islam, A. \& Rahman, M. (2017). Hepatoprotective and antidiabetic effects of nigella sativa seed extract in alloxan -induced diabetic mice: an experimental study with histopathological. World J Pharm. life Sci. 3, 31-38.

11. Bennett, R.N., Mellon, F.A., Foidl, N., Pratt, J.H., Dupont, M.S., Perkins, L. \& Kroon, P.A. (2003). Profiling glucosinolates and phenolics in vegetative and reproductive tissues of the multi-purpose trees Moringa oleifera $\mathrm{L}$. (Horseradish tree) and Moringa stenopetala L. J. Agric. Food Chem. 51, 3546-3553. https://doi.org/10.1021/ jf0211480

12. Bonsnes, R.W \& Taussky, H.H. (1945). On the colorimetric determination of creatinine by the jaffe reaction. J. Biol. Chem., 158, 581-591. https://doi.org/10.1016/s0021-9258 (19)51334-5

13. Centres for Disease Control and Prevention (2017). National Diabetes Statistics Report (2020). Estimates of diabetes and its burden in the United States.

14. Deepthi, B., Sowjanya, K., Lidiya, B., Bhargavi, R. S. \& Babu, P. S. (2017). A modern review of diabetes mellitus: an annihilatory metabolic disorder. $J$ In Silico In Vitro Pharmacol, 3(1).

15. Doumas, B. T., Perry, B. W., Sasse, E. A. \& Straumfjord Jr, J. V. (1973). Standardization in bilirubin assays: evaluation of selected methods and stability of bilirubin solutions. Clinical chemistry, 19(9), 984-993.

16. Đurašević, S., Jasnić, N., Prokić, M., Grigorov, I., Martinović, V., Đorđević, J. \& Pavlović, S. (2019). The protective role of virgin coconut oil on the alloxan-induced oxidative stress in the liver, kidneys and heart of diabetic rats. Food \& Function, 10(4), 2114-2124.

17. Elkotby, D., Hassan, A. K., Emad, R. \& Bahgat, I. (2018). Histological changes in islets of Langerhans of pancreas in alloxan-induced diabetic rats following Egyptian honey 
bee venom treatments. International Journal of Pure and Applied Zoology, 6(1), 1-6.

18. Fahey, J.W., Zalcmann, A.T. \& Talalay, P. (2001). The chemical diversity and distribution of glucosinolates and isothiocyanates among plants. Phytochemistry. https:// doi.org/10.1016/S0031-9422(00)00316-2

19. Fawcett, J.K. \& Scott, J.E. (1960). A rapid and precise method for the determination of urea. J. Clin. Pathol., 13, 156-159. https://doi.org/10.1136/jcp.13.2.156

20. Fossati, P., Prencipe, L. \& Berti, G. (1980). Use of 3,5dichloro-2-hydroxybenzenesulfonic acid/4aminophenazone chromogenic system in direct enzymic assay of uric acid in serum and urine. Clin. Chem. 26, 227 -231. https://doi.org/10.1093/clinchem/26.2.227

21. Francis, J.A., Jayaprakasam, B., Olson, L.K. \& Nair, M.G. (2004). Insulin Secretagogues from Moringa oleifera with Cyclooxygenase Enzyme and Lipid Peroxidation Inhibitory Activities. Helv. Chim. Acta, 87, 317-326. https:// doi.org/10.1002/hlca.200490029

22. Geleta, B. \& Makonnen, E. (2015). Toxicological Evaluations of the Crude Extracts and Fractions of Moringa stenopetala Leaves in Liver and Kidney of Rats. J. Cytol. Histol., 07. https://doi.org/10.4172/2157-7099.1000383

23. Gupta, R., Mathur, M., Bajaj, V.K., Katariya, P., Yadav, S., Kamal, R. \& Gupta, R.S. (2012). Evaluation of antidiabetic and antioxidant activity of Moringa oleifera in experimental diabetes. J. Diabetes 4, 164-171. https://doi.org/10.1111/ j.1753-0407.2011.00173.x

24. Hemant, U., Pradip, S. \& Tarannum, P. (2014). A study on the effects of Moringa oleifera lam. pod extract on alloxan induced diabetic rats. Pelagia Res. Libr. Asian J. Plant Sci. Res. 4, 36-41.

25. Hosseini, A., Shafiee-nick, R. \& Ghorbani, A. (2015). Pancreatic beta cell protection / regeneration with phytotherapy $51,1-16$.

26. Jain, P.G., Patil, S.D., Haswani, N.G., Girase, M. V. \& Surana, S.J. (2010). Atividade hipolipidemica de Moringa oleifera Lam., Moringaceae, na hiperlipidemia induzida por dieta rica em gordura em ratos albinos. Brazilian J. Pharmacogn. 20, 969-973. https://doi.org/10.1590/S0102$695 \times 2010005000038$

27. Jaiswal, D., Kumar Rai, P., Kumar, A., Mehta, S. \& Watal, G. (2009). Effect of Moringa oleifera Lam. leaves aqueous extract therapy on hyperglycemic rats. J. Ethnopharmacol. 123, 392-396. https://doi.org/10.1016/j.jep.2009.03.036

28. Jendrassik \& Grofs BM, (1938). Quantitative colorimetric determination of bilirubin in serum or plasma. Clin Chem 27.

29. Kamalrudin, A., Jasamai, M. \& Noor, M.M. (2018). Ameliorative effect of Moringa oleifera fruit extract on reproductive parameters in diabetic-induced male rats. Pharmacogn. J. 10, S54-S58. https://doi.org/10.5530/ pj.2018.6s.10

30. Kandasamy, N. \& Ashok Kumar, N. (2013). Myricetin modulates streptozotocin-cadmium induced oxidative stress in long term experimental diabetic nephrotoxic rats. J. Funct. Foods 5, 1466-1477. https://doi.org/10.1016/ j.jff.2013.06.004

31. Kar, A., Choudhary, B.K. \& Bandyopadhyay, NG (2003). Comparative evaluation of hypoglycaemic activity of some Indian medicinal plants in alloxan diabetic rats. J. Ethnopharmacol. 84, 105-108. https://doi.org/10.1016/S0378
-8741(02)00144-7

32. Karthikesan, K., Pari, L.\& Menon, V.P. (2010). Combined treatment of tetrahydrocurcumin and chlorogenic acid exerts potential antihyperglycemic effect on streptozotocin -nicotinamide-induced diabetic rats. Gen. Physiol. Biophys. 29, 23-30. https://doi.org/10.4149/gpb_2010_01_23

33. Krentz, A. J., Fujioka, K., \& Hompesch, M. (2016). Evolution of pharmacological obesity treatments: focus on adverse side $\square$ effect profiles. Diabetes, Obesity and Metabolism, 18(6), 558-570.

34. Lal, B.S. (2016). Diabetes: Causes, Symptoms and Treatments, in: Public Health Environment and Social Issue in India, pp. 55-67.

35. Lenzen, S. (2008). The mechanisms of alloxan- and streptozotocin-induced diabetes. Diabetologia 51, 216-226. https://doi.org/10.1007/s00125-007-0886-7

36. Luangpiom, A., Kourjampa, W. \& Junaimaung, T. (2013). Anti-hyperglycemic Properties of Moringa oleifera Lam. Aqueous Leaf Extract in Normal and MildlyDiabetic Mice. Br. J. Pharmacol. Toxicol. 4, 106-109. https://doi.or g/10.19026/bjpt.4.5371

37. Lucchesi, A.N., Cassettari, L.L. \& Spadella, C.T. (2015). Alloxan-induced diabetes causes morphological and ultrastructural changes in rat liver that resemble the natural history of chronic fatty liver disease in humans. J. Diabetes Res. 2015, 1-11. https://doi.org/10.1155/2015/494578

38. Halaby, M. S., Metwally, E. M., \& Omar, A. A. (2013) Effect of Moringa oleifera on serum lipids and kidney function of hyperlipidemic rats. J. Appl. Sci. Res, 9, 51895198.

39. Manohar V.s, Jayasree, T., Kiran Kishore, K., Mohana Rupa, L., Dixit, R. \& Chandrasekhar, N. (2010). Evaluation of hypoglycemic and antihyperglycemic effect of freshly prepared aqueous extract of Moringa oleifera leaves in normal and diabetic rabbits. J. Chem. Pharm. Res. 4, 249 -253 .

40. Mathenge, W., Foster, A., \& Kuper, H. (2010). Urbanization, ethnicity and cardiovascular risk in a population in transition in Nakuru, Kenya: a population-based survey. BMC public health, 10(1), 1-12.

41. Mathers, C.D \& Loncar, D. (2006). Projections of global mortality and burden of disease from 2002 to 2030 . PLoS Med. 3, 2011-2030. https://doi.org/10.1371/journal.pme d.0030442

42. Moyo, B., Oyedemi, S., Masika, P.J. \& Muchenje, V. (2012). Polyphenolic content and antioxidant properties of Moringa oleifera leaf extracts and enzymatic activity of liver from goats supplemented with Moringa oleifera leaves/sunflower seed cake. Meat Sci. 91, 441-447. https://doi.org/10.1016/j.meatsci.2012.02.029

43. Muzumbukilwa, W. T., Kadima, M. G., Nlooto, M., \& Owira, P. M. O. (2019). Mapping the evidence of hepatoprotective properties of Moringa oleifera from subSaharan African countries: a systematic review protocol. Systematic reviews, 8(1), 1-6.

44. Olayaki, L.A., Irekpita, J.E., Yakubu, M.T.\& Ojo, O.O., (2015). Methanolic extract of Moringa oleifera leaves improves glucose tolerance, glycogen synthesis and lipid metabolism in alloxan-induced diabetic rats. J. Basic Clin. Physiol. Pharmacol. 26, 585-593. https://doi.org/10.1515/ jbcpp-2014-0129

45. Omodanisi, E.I., Aboua, Y.G., Oguntibeju, O.O. \& 
Lamuela-Raventós, R.M. (2017). Assessment of the antihyperglycaemic, anti-inflammatory and antioxidant activities of the methanol extract of moringa oleifera in diabetes -induced nephrotoxic male Wistar rats. Molecules 22, 439. https://doi.org/10.3390/molecules22040439

46. Rajanandh MG \& Kavitha J (2010). Quantitative estimation of $\beta$-sitosterol, total phenolic and flavonoid compounds in the leaves of Moringa oleifera, International Journal of PharmTech Research.

47. Reitman, S \& Frankel, S. (1957). A colorimetric method for the determination of serum glutamic oxalacetic and glutamic pyruvic transaminases. Am. J. Clin. Pathol. 28, 5663. https://doi.org/10.1093/ajcp/28.1.56

48. Sanjeevaiah, A., Sushmitha, A. \& Srikanth, T. (2019). Prevalence of Diabetes Mellitus and its risk factors. Int. Arch. Integr. Med. 6, 319-324.

49. Sreekutty, M.S \& Mini, S. (2016). Ensete superbum ameliorates renal dysfunction in experimental diabetes mellitus. Iran. J. Basic Med. Sci. 19, 111-118. https:// doi.org/10.22038/ijbms.2016.6422

50. Sreelatha, S., Jeyachitra, A., \& Padma, P. R. (2011). Antiproliferation and induction of apoptosis by Moringa oleifera leaf extract on human cancer cells. Food and Chemical Toxicology, 49(6), 1270-1275.

51. Tang, Y., Choi, E.-J., Han, W.C., Oh, M., Kim, J., Hwang, J.-Y., Park, P.-J., Moon, S.-H., Kim, Y.S. \& Kim, E.-K
(2017). Moringa oleifera from Cambodia Ameliorates Oxidative Stress, Hyperglycemia, and Kidney Dysfunction in Type 2 Diabetic Mice. J. Med. Food 20, 502-510. https:// doi.org/10.1089/jmf.2016.3792

52. Tende, J.A., Ezekiel, I., Dikko, A.A.U. \& Goji, ADT (2011). Effect of Ethanolic Leaves Extract of Moringa oleifera on Blood Glucose Levels of Streptozocin-Induced Diabetics and Normoglycemic Wistar Rats. Br. J. Pharmacol. Toxicol. 2, 1-4.

53. Toppo, R., Roy, B.K., Gora, R.H., Baxla, S.L. \& Kumar, P. (2015). Hepatoprotective activity of Moringa oleifera against cadmium toxicity: In rats. Vet. World, 8, 537-540. https://doi.org/10.14202/vetworld.2015.537-540

54. Trinder, P. (1969). Determination of blood glucose using an oxidase-peroxidase system with a non-carcinogenic chromogen. J. Clin. Pathol. 22, 158-161.https:// doi.org/10.1136/jcp.22.2.158

55. Vergara-Jimenez, M., Almatrafi, M.M. \& Fernandez, M.L. (2017). Bioactive components in Moringa oleifera leaves protect against chronic disease. Antioxidants 6, 1-13. https://doi.org/10.3390/antiox6040091.

56. Villarruel-López, A., López-de la Mora, D. A., VázquezPaulino, O. D., Puebla-Mora, A. G., Torres-Vitela, M. R., Guerrero-Quiroz, L. A. \& Nuño, K. (2018). Effect of Moringa oleifera consumption on diabetic rats. BMC Complementary and Alternative medicine, 18(1), 1-10. 